\title{
EVALUATION OF COMBINE HARVESTERS FLEET MANAGEMENT
}

\begin{abstract}
Jiř́i MAŠEK, Faculty of Engineering, Czech University of Life Sciences Prague, Kamýcká 129, 16521 Prague, Czech Republic, masekj@tf.czu.cz (corresponding author)

Václav CÍSA ̌̌, Faculty Of Engineering, Czech University Of Life Sciences Prague, Kamýcká 129, 16521 Prague, Czech Republic, cisarv@tf.czu.cz

Combine harvesters play a crucial role in grain harvest. Due to seasonal character of work of these machines is necessary to achieve high standard in durability and reliability during working period. There is lots of requirements that have to be done according to the crop type, field conditions and as well as high performance and lower costs. Combine harvesters are the main harvesting technology of cereals in the world and main piece of work should be done in short time. The aim of this paper is an economic analysis of combine harvester's fleet in different working conditions. The evaluation is based on exact costs analysis of combine harvesters New Holland brand sort by different ages and different concepts of threshing. Used data were collected during all working seasons of combines. There is a data set from 10 seasons. There is two groups in evaluation - 9 machines NH CR 9080 and another 9 machines NH CX 8080. Working parameters evaluated are fuel consumption and operational costs. Thanks to on board computer we have data about performance of each machine per day and per whole season. Costs are calculated as fixed and variable and then summarized for every machine. The result shows that effect of costs analysis depends on annual performance of the machine. There is positive effect on depressing fixed cost due to higher performance in season. A special result of this study is evidence of intervenes reason during all seasons and setting up the coefficient of repairs for the group of combines.
\end{abstract}

Keywords: Combine harvesters, cost, performance

\section{INTRODUCTION}

In nowadays agriculture play combine harvesters an important role in whole food production chain. Combine harvesters must meet a number must a number of criteria - good and early harvest of crops, maintaining grain quality parameters, high efficiency of work and adequate operating costs. A combine harvester is a technics that affects the technological development trends of agriculture just like a tractor (Kutzbach, 2000). Manufactures are continuously improving capacity and work efficiency of modern machines. Many farmers and agricultural companies invested now to the high capacity combines to achieve maximum throughput and threshing performance. Highest quality grain and minimum losses are the standard (Kutzbach, Quick, 1999). This described trend is due to changing of labor force structure in agriculture sector.

Self-propelled harvesting combines are the key machines to realize performance in grain harvesting (Herlitzius et al., 2011) and we can say that it is the main harvesting technology of cereals in the world. A nowadays modern combine harvesters are a versatile machines designed to highest efficiently harvest a wide range of grain crops from the field. Modern combines can harvest more than 80 kinds of grain crops (Miu, 2016). Harvesting of grain crops is a very important task among all working activities in agriculture. Construction or design of combine harvesters must satisfy certain technical and technological requirements according to the crop, weather, environmental and field conditions and postharvesting technologies (Steponavicius, et al., 2011).

In a big farms are usually used fleets of combine harvester. To maintain this fleet we can use different methods Bulgakov et al., (2015) used mathematical model to set optimal size of fleet and all operations connected, or it could be based on practical factors such as distance of dealership, size of farm etc.

There are two main types of combine harvesters - conventional (tangential flow) combines and rotary (axial-flow) combines (Miu, 2016). Conventional combine is characterized by its tangential threshing system with one or two threshing drums and straw walkers as a grain separator, while a rotary combine has an axial-flow integrated threshing and separating system (Kumhála et al., 2007).

The problem from service point of view could be a seasonal character of work in very short period of time, $5-7$ weeks depending on wheatear. Increasing feedrate of combines harvester is occurred (Císař, 2017). It is due to increasing of grain crops production and harvesting time optimizing. Combine harvesters are one of most expensive machines in agriculture. From the perspective of the machinery operator is monitoring of costs and its structure very important.

Copyright (C) 2017 The Authors. Published by Aleksandras Stulginskis University. This is an open-access article distributed under the terms of the Creative Commons Attribution License (CC-BY 4.0), which permits unrestricted use, distribution, and reproduction in any medium, provided the original author and source are credited. 
Structure of operating costs is described by many authors (Beneš et al., 2014; Spokas, Steponavicius, 2011; Olt et al, 2010, Mašek et al., 2017). Evaluation of total operating costs allows to find the right moment for decision making for fleet management - to sell it and buy new one or prepare the machine for general repair. For economic efficiency is recommended to provide the highest possible performance with the lowest possible operating costs (Benes et al., 2014). From fixed costs point of view is necessary to harvest as much as possible area during one season. The highest influence on amount of variable costs has fuel consumption (Spokas, Steponavicius, 2011).

The aim of this study is to evaluate operating costs and repair structure in fleet of combine harvesters in different agricultural companies.

\section{MATERIAL AND METHODS}

Two groups of randomly chosen combine harvesters were put to the evaluation. In first group were 9 combine harvesters NH CX 8080 with conventional (tangential) flow of materials and in second group were 9 axial-flow combine harvesters NH CR 9080 (Fig. 1). This evaluated fleet of combine harvesters was used in different farms and in different field conditions. Data were collected from operational records and from board computer of each machine every year after closing harvesting season.
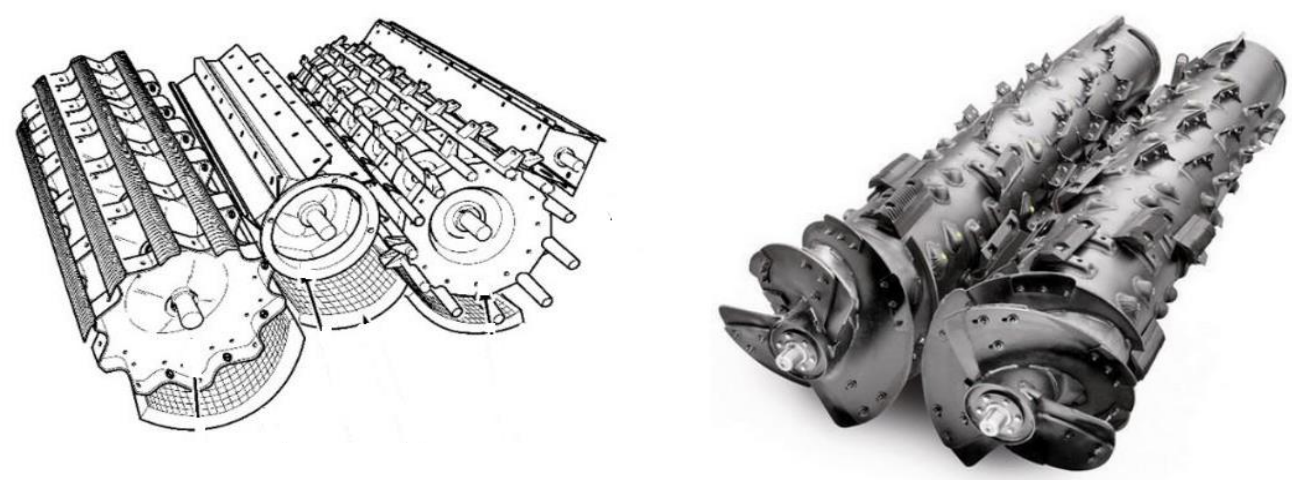

Figure. 1. Working pats of threshing and separating mechanism of NH combine harvester line CX (left) and CR (right).

All combine harvesters observed are in the service from 2006 till 2014. The oldest machine in group was 10 years old and the youngest were 3 years old (Tab. 1). Data were collected on long term bases form 2006 till 2016 season. In both group of combine harvester were calculated in a total 63 season Minimum are 3 harvesting seasons per combine harvester. All machines in observation were equipped with standard $9 \mathrm{~m}$ width header.

Evaluation data are as follows: total used fuel, total harvested area, engine and trashing hours, costs of spare parts, filters, fluids, amount of service labor hours, the cost of labor, frequency of mechanical, electrical, hydraulic, number of maintenance interventions/service operations.

Calculation of coefficient of repairs for machines is based on calculation of total costs of repairs and spare parts during technical life and its comparison with price of machine. The coefficient says how much many user pay for service and maintenance of machine during its technical life.

Total cost $\mathrm{C}_{\text {Total }}$ expended on the machine is calculated as sum of fixed and variable costs.

$$
C_{\text {Total }}=C_{F}+C_{V}
$$

Fixed costs $\mathrm{C}_{\mathrm{F}}$ (formula 2) based on:

- depreciation cost $\mathrm{C}_{\mathrm{D}}$;

- insurance cost $\mathrm{C}_{\mathrm{I}}$;

- garage place cost $\mathrm{C}_{\mathrm{G}}$;

$$
C_{F}=C_{D}+C_{I}+C_{G}
$$

Variable costs $\mathrm{C}_{\mathrm{V}}$ (formula 3 ) based on:

- fuel costs $\mathrm{C}_{\mathrm{FC}}$;

- costs of maintenance, repairs and servicing $\mathrm{C}_{\mathrm{RS}}$;

- labour costs for operators of the combine harvester $\mathrm{C}_{\mathrm{LO}}$.

$$
C_{\text {Total }}=C_{F C}+C_{R S}+C_{L O}
$$

The costs of maintenance, repair and service $C_{R S}$ were read out from the company accounting system and from service partner.

Calculation of coefficient of repairs $\left(C O_{R P}\right)$ is based on sale price of combine harvester $\left(P_{T O T}\right)$ and costs of maintenance, repairs and servicing $\left(C_{R S}\right)$ : 


$$
C O_{R P}=\frac{P_{T O T}}{C_{R S}}
$$

Table 1. Summary of combine harvesters' parameters in evaluation

\begin{tabular}{|c|c|c|c|c|c|c|c|}
\hline COMBINE & $\begin{array}{l}\text { Total } \\
\text { Working } \\
\text { Engine } \\
\text { (Mth) }\end{array}$ & $\begin{array}{c}\text { Total } \\
\text { Working } \\
\text { Threshing } \\
\text { (Mth) }\end{array}$ & $\begin{array}{c}\text { Working } \\
\text { threshing } \\
\text { (Mth/year) }\end{array}$ & $\begin{array}{c}\text { Total } \\
\text { harvested } \\
\text { area (ha) }\end{array}$ & $\begin{array}{c}\text { Total fuel } \\
\text { consumption } \\
\text { (1) }\end{array}$ & $\begin{array}{c}\text { Av. fuel } \\
\text { consumption } \\
\text { (1/ha) }\end{array}$ & $\begin{array}{c}\text { Seasons } \\
\text { number } \\
\text { (y ear) }\end{array}$ \\
\hline CR 980_1 & 3606 & 2611 & 237,4 & 7395 & 110608 & 15,0 & 11 \\
\hline CR 9080_2 & 2066 & 1556 & 155,6 & 4092 & 65916 & 16,1 & 10 \\
\hline CR 9080_3 & 2821 & 2030 & 225,6 & 6327 & 111191 & 17,6 & 9 \\
\hline CR 9080_4 & 1754 & 1357 & 193,9 & 4322 & 82438 & 19,1 & 8 \\
\hline CR 9080_5 & 2190 & 1550 & 221,4 & 4889 & 86878 & 17,8 & 7 \\
\hline CR 9080_6 & 1270 & 993 & 165,5 & 2972 & 57764 & 19,4 & 6 \\
\hline CR 9080_7 & 979 & 745 & 149 & 2346 & 38602 & 16,5 & 5 \\
\hline CR 9080_8 & 1100 & 768 & 192 & 2280 & 46160 & 20,2 & 4 \\
\hline CR 9080_9 & 697 & 485 & 161,7 & 1533 & 23838 & 15,5 & 3 \\
\hline CX 860_1 & 2714 & 2162 & 196,6 & 6124 & 85651 & 14,0 & 11 \\
\hline CX 8080_2 & 2424 & 1766 & 176,6 & 4379 & 71523 & 16,3 & 10 \\
\hline CX 8080_3 & 2568 & 1771 & 196,8 & 4406 & 71395 & 16,2 & 9 \\
\hline CX 8080_4 & 1326 & 987 & 169,6 & 3062 & 44687 & 14,6 & 8 \\
\hline CX 8080_5 & 1572 & 1159 & 165,6 & 3185 & 51844 & 16,3 & 7 \\
\hline CX 8080_6 & 1392 & 1082 & 180,3 & 2972 & 45557 & 15,3 & 6 \\
\hline CX 8080_7 & 859 & 668 & 133,6 & 2087 & 27953 & 13,4 & 5 \\
\hline CX 8080_8 & 688 & 556 & 139 & 1653 & 22434 & 13,6 & 4 \\
\hline CX 8080_9 & 487 & 365 & 121,7 & 1085 & 14876 & 13,7 & 3 \\
\hline
\end{tabular}

\section{RESULTS AND DISCUSSION}

The main emphasis in evaluation of variable costs was put on maintenance, service and spare parts for every machine in observed group. It was counted number of interventions to different group of combines' mechanism and systems - mechanical, electrical and hydraulics and general maintenance before harvest season. Summarized results as total number of interventions are shown in Fig. 2. According to results, is possible say, that there is no difference in number of interventions between CR and CX combine. $57 \%$ of all service work ware done in mechanical way, electrical $(17-21 \%)$ and only $8 \%$ of interventions were done in hydraulics.

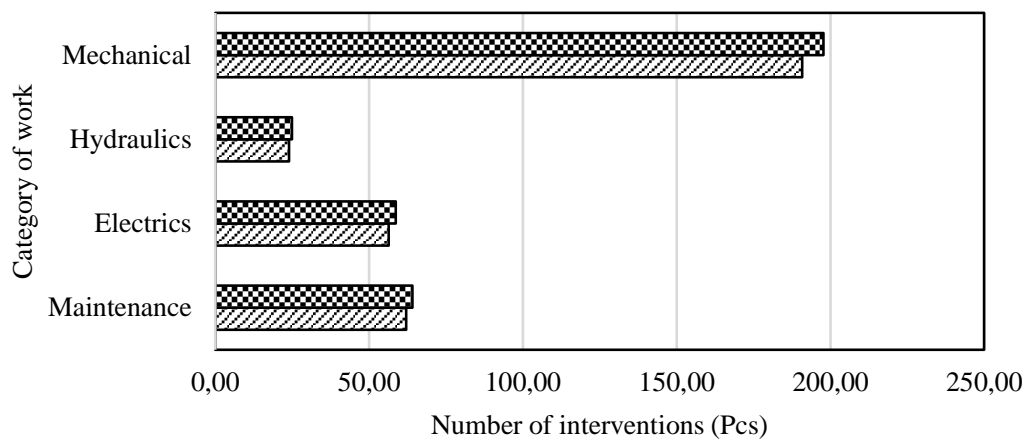

$\triangle \mathrm{CX} \square \mathrm{CR}$

Figure 2. Number of interventions during all working seasons. 
Evaluation of fuel consumption during harvest is consistent with results of other authors (Beneš et al., 2014, Spokas, Stepanovicus, 2011). Axial flow combine harvester has significantly higher average fuel consumption per 1 ha harvested. Average diesel consumption 17.2 1.ha-1 was set up in evaluated group of combine harvesters with axial flow and for tangential flow model it was $15.11 \mathrm{ha}^{-1}$. All data was processed in STATISTICA software, tools ANOVA. There was confirmed significant difference between tangential and axial threshing mechanism in fuel consumption on chosen level of relevance $(\alpha=0.05)$.

More interesting evaluation is determination of the repairs coefficient $C O_{R P}$. There was calculated all service, maintenance and spare parts costs during all season of utilizations of every machine and thereafter compared with specific machine sale price.

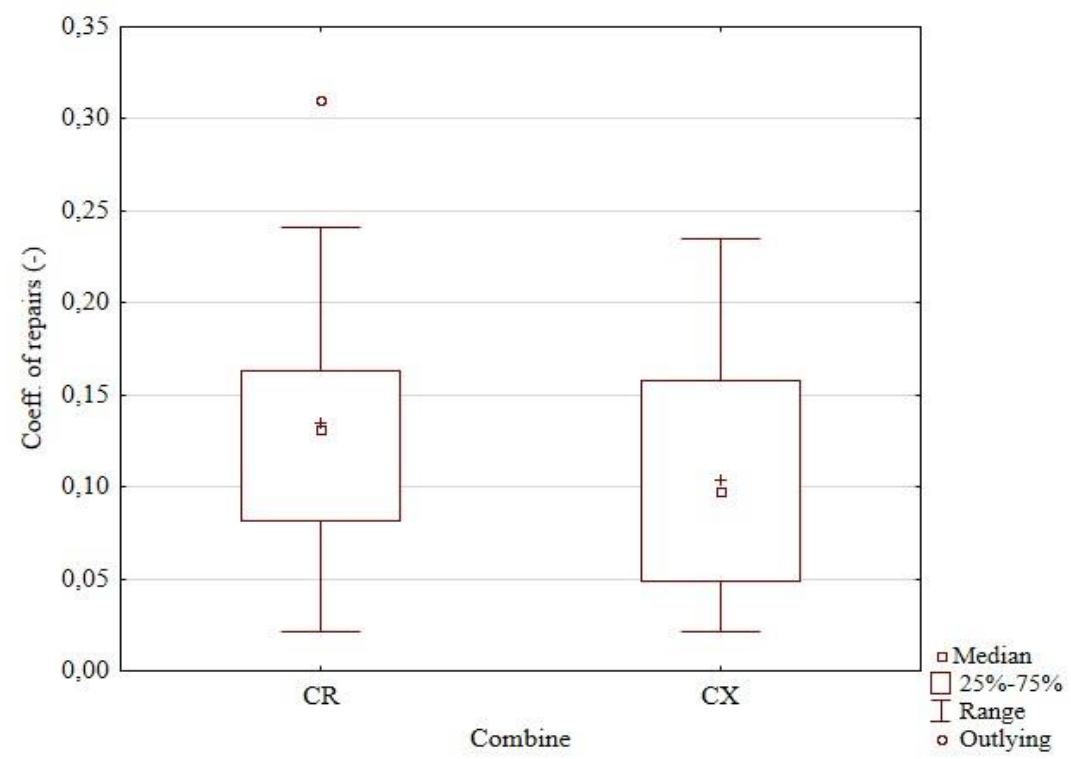

Figure 3. Evaluation of repairs' coefficient (ANOVA results).

Total values $C_{R P}$ in compared group of machines are setting on 0.135 for $\mathrm{CR}$ machines and 0,103 for $\mathrm{CX}$ machines. There is no significant difference (Fig. 3) between CR and CX model line on chosen level of relevance $(\alpha=0.05)$. It means that during the technical life is necessary to invest $13.5 \%$ (by CR) or $10.3 \%$ (by CX) from sale price of machine to the spare parts and service work (accident damages excluded).

\section{CONCLUSION}

1. Service and maintenance interventions structure, compare mechanics, electrics and hydraulic systems, is without significant difference between tangential and axial flow combine harvesters.

2. Axial flow combine harvesters have higher fuel consumption compare to tangential units. But axial combine harvesters achieve higher performance due to higher material throughput during threshing process.

3. $C O_{R P}$ values of evaluated machines are without statistical significant difference between machines CX and CR. During technical life of the selected group of combine harvester is approx. $10-13 \%$ of combine harvesters' price necessary spent for service and repairs.

4. Total operating costs and $C O_{R P}$ values are strong tools for decision making in combine harvesters fleet management.

\section{REFERENCES}

1. Benes. L., Novak, P., Masek, J., Petrasek, S. 2014. John Deere combine harvesters fuel consumption and operation costs. Proceedings of the International Scientific Conference "Engineering for Rural Development 2014", May 29.-30., Jelgava, pp. 13-17, Latvian University of Agriculture.

2. Bulgakov, V., Adamchuk, V., Arak, M., Olt, J. 2015. Mathematical modelling of the process of renewal of the fleet of combine harvesters. Agriculture and Agricultural Science Procedia, Vol. 7, 35-39. https://doi.org/10.1016/j.aaspro.2015.12.027

3. Císař, V. 2017. Evaluation of New Holland combine harvesters in Czech Republic conditions. MSc diploma thesis. FE CULS Prague, 104 p. [In Czech]

4. Herlitzius, T., Mueller, H., Kranke, G., Wittig, H., Wolf, J. 2011. Concept Study of a Self-Propelled Harvester versus a Modular System. Proceedings of International Conference "Landtechnik AgEng 2011", November 11-12, Hannover, pp. 69-75, VDI-MEG.

5. Kumhala, F. et al. Zemedelská technika - stroje a technologie pro rostlinnou výrobu. First edition. Prague: CULS Prague, 2007. 426 p. [In Czech]

6. Kutzbach, H.D., Quick, G.R. 1999. Harvesters and threshers. In CIGR Handbook of Agricultural Engineering. Vol. III. Plant Production Engineering, ed. B.A. Stout, 311-347. St. Joseph, MI: American Society of Agricultural Engineers. 
7. Kutzbach H.D. 2000. Trends in Power and Machinery. Journal of Agricultural Engineering Research, Vol. 76, pp. $237-247$. https://doi.org/10.1006/jaer.2000.0574

8. Mašek, J., Novak, P., Jasinskas, A. 2017. Evaluation of combine harvester operation costs in different working conditions. Proceedings of the International Scientific Conference "Engineering for Rural Development 2017”, May 24.-26., Jelgava, pp.1180-1185, Latvia University of Agriculture.

9. Miu, P. 2016. Combine Harvesters - Theory, Modeling and Design. CRC Press, 2016. 437 p.

10. Olt, J., Traat, Ü., Küüt, A. 2010. Maintenance costs of intensively used self-propelled machines in agricultural companies. Proceedings of the International Scientific Conference "Engineering for Rural Development 2010", May 27.-28. Jelgava, pp. 42-48, Latvia University of Agriculture.

11. Spokas, L., Steponavicius, D. 2011. Fuel consumption during cereal and rape harvesting and methods of its reduction. Journal of Food Agriculture \& Environment, Vol. 9, No. 3-4, pp. 257-263.

12. Steponavicius, D., S. Petkecius, and R. Domeika. 2011. Determination of rational values of inclination angles of straw walker sections. Proceedings of the International Scientific Conference "Engineering for Rural Development 2011", May 26.-27, pp. 76-81. Latvia University of Agriculture. 